\title{
A Comparative Clinical Study on Surgical Blade and Diode Laser in the Treatment of Gingival Melanin Pigmentation
}

\author{
Somit Kumar Jain ${ }^{1}$, Nina Shenoy², Mehul Kumar Chourasia ${ }^{3}$, Amitha Ramesh ${ }^{4}$ \\ 1, 2, 4 Department of Periodontics, Nitte (Deemed to Be University), AB Shetty Memorial Institute of Dental \\ Sciences (ABSMIDS), Mangalore, India. ${ }^{3}$ Department of Population Health and Genomics, \\ School of Medicine, University of Dundee, United Kingdom.
}

\section{ABSTRACT}

\section{BACKGROUND}

Gingival melanin pigmentation (GMP) is a common aesthetic concern. The gold standard for depigmentation, is surgery. Recently soft tissue lasers have gained popularity. The purpose of this study was to compare and evaluate the clinical efficacy of surgical blade and laser treatment in terms of pain perception and wound healing outcomes, 7 and 14 days following the procedures for the treatment of gingival depigmentation.

\section{METHODS}

This 14 day follow up comparative clinical study, utilized a split mouth design, in the anterior region. Fifteen patients with moderate to heavy bilateral gingival pigmentation were included as per the criteria by Dummett et al. The patients' right side (group 1) was treated with surgical blade and the left side (group 2) with diode laser (Picasso, AMD LASERS ${ }^{\mathrm{TM}}$ ) by a trained clinician. Pain perception was assessed using Visual Analog Scale (VAS) and wound healing was assessed using clinical parameters.

\section{RESULTS}

Data was analysed using paired t test and Wilcoxon's signed rank test. P value of < 0.05 was considered statistically significant. On day 7 , more than $70 \%$ patients had slight pain in group 1 . Whereas, $47 \%$ experienced no pain in group 2 . The mean difference in VAS scores between the groups at day 7, was statistically significant. No statistically significant distinction in wound healing was observed 7 days following both procedures. No pain, and complete epithelialisation was noted in both groups on day 14.

\section{CONCLUSIONS}

Pain experienced by the patients was slightly more in the scalpel group compared to laser. There was no difference in wound healing between both groups.

\section{KEY WORDS}

GMP, Gingival Melanin Pigmentation, VAS Scale, Depigmentation, Wound Healing, Laser, Surgical Blade, Split Mouth Design
Corresponding Author: Dr. Nina Shenoy, Professor,

Department of Periodontics, Nitte (Deemed to Be University), AB Shetty Memorial Institute of Dental Sciences (ABSMIDS), Mangalore, -575018, India. E-mail: ninashenoy@gmail.com

DOI: $10.14260 /$ jemds/2021/148

How to Cite This Article: Jain SK, Shenoy N, Chourasia MK, et al. A comparative clinical study on surgical blade and diode laser in the treatment of gingival melanin pigmentation. J Evolution Med Dent Sci 2021;10(10):689-693, DOI: 10.14260/jemds/2021/148

Submission 06-11-2020,

Peer Review 17-01-2021,

Acceptance 23-01-2021,

Published 08-03-2021.

Copyright (C) 2021 Somit Kumar Jain et al. This is an open access article distributed under Creative Commons Attribution License [Attribution 4.0 International (CC $B Y 4.0)]$ 


\section{BACKGROUND}

Gingival melanin pigmentation is one of the aesthetic concerns amongst people. ${ }^{1}$ Several factors determine the colour of gingiva, such as the number and size of blood vessels, thickness of the epithelium, amount of keratinization and pigments within the epithelium. The colour varies among different persons and appears to be correlated with the cutaneous pigmentation.2,3 Synthesis of melanin granules occurs in melanosomes of the melanocytes present in the human gingiva. ${ }^{4}$ Gingival hyperpigmentation has been observed in all the races, it could be physiological, pathological or genetic. Thus, the colour of the gingiva varies from pink (pale) to brownish (blackish) among the Caucasians to Indian, Asians (and Africans).5,6 Physiological gingival pigmentation can be the result of various endogenous or exogenous factors. Moreover, oral pigmentation can be caused by various etiological factors such as tobacco smoking, chewing betel nut and certain medications such as minocycline, ketoconazole, and oral contraceptives. ${ }^{7}$

A critical aspect related to depigmentation procedures is the reported occurrence of repigmentation. In cases where incomplete removed pigmented tissue occurs especially in the interdental papilla region, the active melanocytes from adjacent pigmented tissues may migrate to the treated areas, causing reoccurrence of pigmentation.

Various methods and techniques have been used in the cosmetic therapy of GMP such as scalpel blade surgery, chemical method, gingivectomy alone or with free gingival auto-grafting, electro surgery, cryosurgery, abrasion with diamond bur and different types of lasers including $\mathrm{CO}^{2}$, Nd:YAG, Er:YAG and Diode laser.8,9 Recently laser surgery has become an effective, suitable, and reliable technique for treating GMP and is a treatment of choice among clinicians. ${ }^{10,11}$ Scalpel surgical method is an easier, cost effective modality compared to other techniques necessitating complex armamentarium. However, scalpel surgery can cause unnecessary bleeding during the procedure, a periodontal dressing may also be vital. ${ }^{12}$ Uses of $\mathrm{Nd}$ : YAG and $\mathrm{CO}_{2}$ lasers have reported to overcome such drawbacks with similar postoperative results with additional advantages of lesser bleeding complications and postoperative pain. $13,14,15$ Sterilisation of the wound site, less swelling and minimal scarring are additional advantages of using these lasers. ${ }^{16,17}$ Diode laser, an alternate system is a solid-state semiconductor laser with a combination of gallium (Ga), arsenide (Ar), and other elements for conversion of energy from electrical to light energy. ${ }^{18}$ Diode lasers with a wavelength of 800 to $980 \mathrm{~nm}$, allows a higher absorption by soft tissue, water particles, and melanin chromophores. ${ }^{19}$ Hence, this split-mouth clinical study was designed to evaluate and compare the clinical efficacy in terms of pain and wound healing outcomes, using both scalpel blade and the diode laser technique for gingival depigmentation.

\section{METHODS}

In this comparative clinical study, the participants were recruited from the outpatient department of the dental college from August 2012 to February 2014. Institutional research and ethics board approval was obtained prior to initiation of the study. The research protocol complies with the Declaration of Helsinki. Written informed consent was obtained from all participants.

Fifteen patients ( 9 females, 6 males) in the age range of 18 - 35 years, with aesthetic complaints of gingival melanin pigmentation bilaterally in the anterior portion of the maxillary labial gingiva were recruited. Only gingiva that was categorised as either moderate (medium brown or mixed pink or brown tissue) or with heavy clinical pigmentation (deep brown or blue / black tissue) according to the criteria by Dummett et al. ${ }^{20}$ was included in the study.

Patients with any positive medical history such as diabetes, endocrine diseases and / or drugs associated with pathologic melanin pigmentation, pregnancy and history of smoking, were excluded.

A single trained clinician treated all the recruited patients.

\section{A Split-Mouth Design was Used}

Group 1 - Gingival depigmentation on the patient's right maxillary quadrant was performed by the surgical blade (no. 15) extending from central incisor to the first premolar.

Group 2 - Gingival depigmentation on the patient's left maxillary quadrant was performed by diode laser irradiation extending from central incisor to the first premolar.

\section{Pre-Operative Assessment}

The assessment of gingival hyperpigmentation was done under adequate light with a mouth mirror using DummettGupta Oral Pigmentation Index (DOPI) ${ }^{20}$ data was recorded pre-operatively. Distribution of GMP was recorded in each gingival unit, which comprised of interdental papilla with either side of half marginal gingiva and its associated attached gingiva.

\section{Post-Operative Evaluation}

After completion of the depigmentation procedure, the patients were subsequently recalled at 7 and 14 days. Pain perception was evaluated by an independent observer with Visual Analogue Scale of $10 \mathrm{~cm}$ with numbers marked, the left side indicating less and right indicating more pain. ${ }^{21}$ Wound healing was assessed at day 7 and 14 by scoring criteria 0 tissue defect or necrosis, 1 - ulcer, 2 - incomplete or partial epithelisation, and 3 - complete epithelisation.15,16

\section{Technique Used for Depigmentation} Surgical Stripping Procedure

Firstly, local anaesthesia, $2 \%$ lignocaine hydrochloride with adrenaline $(1: 80,000)$ was infiltrated. Thereafter, with the scalpel blade (no. 15) surgical stripping was carried out in the pigmented gingival areas from anterior part of maxillary arch to the first premolar. All the melanin pigment fragments were methodically removed from the mucogingival junction towards the tip of the interdental papilla. A post-surgical 
periodontal dressing was placed on the operated gingival area. Patients were re-evaluated on the $7^{\text {th }}$ and $14^{\text {th }}$ day of surgery.

\section{Laser Procedure}

Before application of the lasers, four parameters - wavelength, type of wave, pulse duration and energy output of the lasers need to be confirmed.

All the safety precautions for patient and operator provided by the manufacturer were followed. ${ }^{22}$ Following local infiltration ( $2 \%$ lignocaine hydrochloride) laser ablation of the pigmented tissue was carried out with gallium aluminium arsenide ( $\mathrm{GaAl}$ As) diode laser device (Picasso, AMD LASERS $^{\text {TM }}$ ). Continuous contact mode using the fibreoptic tip with diameter of $320 \mu \mathrm{m}$, with continuous wavelength of $808 \mathrm{~nm}$ at 0.5 to 1.2 -watt power setting, was used in a brush stroke movement until the entire pigmented area was covered. The laser tip and the operating field was systematically cleaned and mopped with a saline-moistened sterile cotton pad for clear visibility. The laser procedure was carried out in the left quadrant in a cervico-apical direction in the pigmented areas. Postoperative instructions were given to the patients and follow-up was done on $7^{\text {th }}, 4^{\text {th }}$ day of surgery.

\section{Statistical Analysis}

Wilcoxon's signed rank test was used to assess the difference in wound healing between two treatment procedures. Paired $t$ test was used to assess the difference in pain between the two groups. $\mathrm{P}$ value $<0.05$ was considered as statistically significant. Statistical analysis was carried out using the SPSS software version 16.

\section{RESULTS}

\begin{tabular}{|c|c|c|c|c|c|}
\hline Pain Category (VAS) & $\begin{array}{c}\text { Group } 1 \\
\text { Scalpel Blade } \\
\text { N (\%) }\end{array}$ & \multicolumn{2}{|c|}{$\begin{array}{c}\text { Group } 2 \\
\text { Laser } \\
\text { N (\%) }\end{array}$} & \multicolumn{2}{|c|}{ Total } \\
\hline No pain & 03 (20\%) & \multicolumn{2}{|c|}{07 (46.7 \%) } & \multicolumn{2}{|c|}{10} \\
\hline Slight pain & $11(73.4 \%)$ & \multicolumn{2}{|c|}{08 (53.3 \%) } & \multicolumn{2}{|c|}{19} \\
\hline Moderate pain & $01(6.6 \%)$ & \multicolumn{2}{|c|}{$0(0 \%)$} & \multicolumn{2}{|c|}{01} \\
\hline Total & $15(100 \%)$ & \multicolumn{2}{|c|}{15 (100\%) } & \multicolumn{2}{|c|}{30} \\
\hline \multicolumn{6}{|c|}{ Paired Samples test to compare the difference in post-operative pain after 7 days } \\
\hline \multirow[t]{2}{*}{ Paired Differences } & \multirow[t]{2}{*}{$\begin{array}{c}\text { Mean Standard } \\
\text { Difference Deviation }\end{array}$} & \multicolumn{2}{|c|}{$\begin{array}{l}95 \% \text { Confidence } \\
\text { Interval }(\mathrm{CI}) \text { of } \\
\text { Difference }\end{array}$} & \multirow{2}{*}{\multicolumn{2}{|c|}{$\begin{array}{cc}\mathbf{t} & \mathbf{P} \\
\text { Value } & \text { Value }\end{array}$}} \\
\hline & & Lower & Upper & & \\
\hline $\begin{array}{c}\text { Visual analog scale for } \\
\text { laser at } 7 \text { days - visual } \\
\text { analog scale for surgical } \\
\text { blade at } 7 \text { days }\end{array}$ & -1.000 & -1.750 & -1.513 & -0.487 & $0.01^{*}$ \\
\hline $\begin{array}{r}\text { Table } 1 . \\
7 \mathrm{Da}\end{array}$ & $\begin{array}{l}\text { Difference in Postol } \\
\text { ays in the Scalpel Bl }\end{array}$ & $\begin{array}{l}\text { perative } \\
\text { ade and }\end{array}$ & $\begin{array}{l}\text { Pain afte } \\
\text { Laser }\end{array}$ & & \\
\hline
\end{tabular}

This split-mouth clinical study included a total of fifteen patients. Sixty percent of the patients in the study group were females and $40 \%$ were male.

Table 1 depicts that nearly $73 \%$ of the patients in group 1 experienced slight postoperative pain, whereas, $53 \%$ in group 2 experienced slight pain. There was a statistically significant difference in perception of pain (VAS) between the groups on the $7^{\text {th }}$ day. No pain was reported in both groups on day 14 . On the $7^{\text {th }}$ day, several areas treated in group 1 , were completely epithelised (5 / 15) than the areas in group 2 (2 / 15), with no statistically significant difference in the wound healing response. However, irrespective of the treatment modality, all the treated gingival areas were completely epithelised after 14 days (Table 2)

\begin{tabular}{|c|c|c|c|c|c|c|}
\hline \multirow{2}{*}{$\begin{array}{c}\text { Days } \\
\text { Wound Healing }\end{array}$} & \multicolumn{2}{|c|}{7 Days } & \multicolumn{4}{|c|}{14 Days } \\
\hline & Scalpel & Diode & Total & Scalpel & Diode & Total \\
\hline $\begin{array}{c}\text { Complete } \\
\text { epithelisation }\end{array}$ & 5 & 2 & 7 & 15 & 15 & 30 \\
\hline $\begin{array}{l}\text { Incomplete } \\
\text { epithelisation }\end{array}$ & 7 & 9 & 16 & 0 & 0 & 0 \\
\hline Ulcer & 3 & 4 & 7 & 0 & 0 & 0 \\
\hline Tissue necrosis & 0 & 0 & 0 & 0 & 0 & 0 \\
\hline Total & 15 & 15 & 30 & 15 & 15 & 30 \\
\hline \multicolumn{7}{|c|}{ Wilcoxon Signed Rank test to Compare the difference in Wound Healing After 7 days } \\
\hline \multicolumn{2}{|c|}{$\begin{array}{c}\text { Wound Healing } \\
\text { after } 7 \text { Days }(\mathrm{N}=15)\end{array}$} & Mean (SD) & Minimum & Maximum & $\mathbf{Z}$ & $\begin{array}{c}P \\
\text { Value }\end{array}$ \\
\hline \multicolumn{2}{|c|}{ Group 1 - Diode laser } & $2.13(0.64)$ & 1 & 3 & \multirow{2}{*}{-1.633} & \multirow{2}{*}{0.102} \\
\hline Group 2 - Surgica & 1 blade & $1.87(0.74)$ & 1 & 3 & & \\
\hline \multicolumn{7}{|c|}{$\begin{array}{c}\text { Table 2. Difference in Wound Healing after } 7 \text { and } 14 \\
\text { Days in the Postoperative Period in the Gingival } \\
\text { Area Treated with Scalpel Blade and Laser }\end{array}$} \\
\hline \multicolumn{7}{|c|}{-value significant at $<0.05$} \\
\hline
\end{tabular}

\section{DISCUSSION}

Treatment was provided to fifteen patients, in the anterior maxillary region. The right quadrant was de- epithelialized by scalpel blade and the left side by diode laser. Postoperative pain and wound healing were evaluated on $1^{\text {st }}$ and $2^{\text {nd }}$ week of surgery. The difference in pain perception after 1 week was assessed using VAS scores in both groups. Out of 15 patients treated with the scalpel blade, only $20 \%$ reported no pain. Whereas, in group 2, nearly $50 \%$ of the patients had no pain (Table 1). No pain was reported at 14 days in both the groups. Overall, patients experienced significantly less pain in the laser sites compared to the scalpel blade sites which are in concurrence with the studies done by Lagdive $\mathrm{S}$ and Mani et al. ${ }^{21,23}$ Protein coagulum formed on the wound surface can act as a biological dressing. Similarly, the laser can seal the ends of sensory nerves causing reduction of pain. ${ }^{23,24}$ Although, pain is a subjective phenomenon and depends on the tolerance level of the individual and perception level of the person.

Wound healing between the two groups was compared at $7^{\text {th }}$ and $14^{\text {th }}$ day. Complete epithelisation was observed in 33 $\%$ and $13 \%$ of patients treated with a scalpel blade and diode laser respectively. The studies by Mani et al. and Ozbayrac et al. reported quicker wound healing for the scalpel blade than the diode laser. ${ }^{23,25}$

Although clinically, a higher number of ulcers and incomplete epithelisation was noted in the laser group. No statistically significant difference was observed in the healing on day 7 in both groups (Table 2). Complete epithelialisation was noted in both groups on day 14 . There are several reports of better visual healing with the laser $26,27,28$ which was in contrast to this study. Slight bleeding was reported in both groups during the procedure, although there were no reports of bleeding after 1 week and 14 days following the procedure in either group. Laser procedure may have another fine advantage that it can neatly take away a thin epithelium layer causing less damage to underlying gingiva and bony structures. ${ }^{29}$

Aesthetic complaints of gingival pigmentation in young patients are commonly encountered in clinical settings. 
Surgical blade technique is a well-established with sufficient evidence in the literature of its use. It is economical, simple and effective with the need for very less armamentarium. Laser on the other hand requires additional cost, training and safety measures for the operator and patient. There is sufficient evidence to indicate that lasers provide a sterile, bloodless field with reduced bacteraemia, trauma and pain. Lasers, however, have to be operated with care since incorrect application may damage gingiva and alveolar bone which, in turn, can cause gingival recession and delayed wound healing.

A positive aspect pertaining to this study was the split mouth design, hence, the wound healing and pain perception were evaluated for both procedures in the same patient. Additionally, a single trained clinician performed both procedures.

The main disadvantage of depigmentation procedures is the recurrence. Recent literature indicated no recurrence 25 years following surgical depigmentation. ${ }^{30}$ Although studies report better pain relief utilising diode laser, a clear disadvantage is an extended length of treatment time required to treat heavy pigmented areas. More clinical expertise is required for utilising lasers.

Although slightly pain experienced was more in group 1 , in terms of wound healing no difference was observed between the groups. Hence, both techniques proved to be equally effective in the treatment of gingival pigmentation.

\section{CONCLUSIONS}

Gingival depigmentation procedures have become very common and are routinely carried out. Patients experienced slightly more pain in the scalpel group compared to laser. However, there was no difference in wound healing between both groups.

Within the limitations of this study, it can be concluded that both scalpel and laser techniques provide effective and satisfactory results. Surgical blade technique, which is the gold standard, is a relatively inexpensive option for patients who cannot afford more contemporary techniques.

However, there is a need for randomised controlled trials taking into consideration the tissue biotype and assessing the recurrence of gingival melanin pigmentation in the future.

\footnotetext{
Limitations

This study had only 15 patients. The gingival thickness / biotype of patients and the recurrence of pigmentation was not taken into consideration. Hence, further comparative studies including more parameters can provide a decisive inference.

Data sharing statement provided by the authors is available with the full text of this article at jemds.com.

Financial or other competing interests: None.

Disclosure forms provided by the authors are available with the full text of this article at jemds.com.

We would like to thank all the patients for their consent, valuable time and cooperation.
}

\section{REFERENCES}

[1] Esen E, Haytac MC, Oz IA, et al. Gingival melanin pigmentation and its treatment with the $\mathrm{CO} 2$ laser. Oral Surg Oral Med Oral Pathol Oral Radiol Endod 2004;98(5):522-7.

[2] Eid HA, Syed S, Soliman AN. The role of gingival melanin pigmentation in infl ammation of gingiva, based on genetic analysis. J Int Oral Health 2013;5(4):1-7.

[3] Fiorellini JP, Kim DM, Uzel NG. Anatomy of the periodontium. In: Newman MG, Takei HH, Klokkevold PR, et al. eds. Carranza's Clinical Periodontology. $12^{\text {th }}$ edn. Los Angeles, California: Elsevier 2015: p. 9-39.

[4] Hanioka T, Tanaka K, Ojima M, et al. Association of melanin pigmentation in the gingiva of children with parents who smoke. Pediatrics 2005;116(2):186-90.

[5] Manson JD, Eley BM. Outline of Periodontics. $4^{\text {th }}$ edn. Oxford: Butterworth Heinemann 2000.

[6] De Krom CJ, van Waas MA, Oosterveld P, et al. The oral pigmentation chart: a clinical adjunct for oral pigmentation in removable prostheses. Int J Prosthodont 2005;18(1):66-70.

[7] Suthprasertporn S. Treatment of Gingival Melanin hyperpigmentation by Er, Cr: YSGG laser: report of 2 cases. Thai J Periodontol 2007;1:46-55.

[8] Lin YH, Tu YK, Lu CT, et al. Systematic review of treatment modalities for gingival depigmentation: a random-effects poisson regression analysis. J Esthet Restor Dent 2014;26(3):162-78.

[9] Prasad SSV, Agarwal N, Reddy NR. Gingival depigmentation: a case report. People's Journal of Scientific Research 2010;3(1):27-9.

[10] Arikan F, Gürkan A. Cryosurgical treatment of gingival melanin pigmentation with tetrafluoroethane. Oral Surg Oral Med Oral Pathol Oral Radiol Endod 2007;103(4):452-7.

[11] Deepak P, Sunil S, Mishra R, et al. Treatment of gingival pigmentation: a case series. Indian J Dent Res 2005;16(4):171-6.

[12] Humagain M, Nayak DG, Uppoor AS. Gingival depigmentation: a case report with review of literature. Journal of Nepal Dental Association 2009;10(1):53-6.

[13] Urmi D, Jasuma RJ, Deepak D, et al. Comparison of patient perception on gingival depigmentation using scalpel and diode laser. Journal of Dental and Medical Sciences 2013;11(4):33-8.

[14] Atsawasuwan P, Greethong K, Nimmanon V. Treatment of gingival hyperpigmentation for aesthetic purposes by $\mathrm{Nd}$ : YAG laser: report of 4 cases. J Periodontol 2000;71(2):315-21.

[15] Ishii S, Aoki A, Kawashima Y, et al. Application of an Er: YAG laser to remove gingival melanin hyperpigmentation: treatment procedure and clinical evaluation. J Jpn Soc Laser Dent 2002;13:89-96.

[16] Pavlic V, Brkic Z, Marin S, et al. Gingival melanin depigmentation by Er: YAG laser: a literature review. J Cosmet Laser Ther 2018;20(2):85-90.

[17] Tal H, Oegiesser D, Tal M. Gingival depigmentation by erbium: YAG laser: clinical observations and patient responses. J Periodontol 2003;74(11):1660-7. 
[18] Coluzzi DJ. An overview of laser wavelength used in dentistry. Dent Clin North Am 2000;44(4):753-65.

[19] Kaya GS, Yavuz GY, Sumbullu MA, et al. A comparison of diode laser and Er: YAG lasers in the treatment of gingival melanin pigmentation. Oral Surg Oral Med Oral Pathol Oral Radiol Endod 2012;113:293-9.

[20] Dummett CO, Gupta OP. The DOPI assessment in gingival pigmentation. J Dent Res 1966;45:122.

[21] Lagdive S, Doshi Y, Marawar PP. Management of gingival hyperpigmentation using surgical blade and diode laser therapy: a comparative study. J Oral Laser Applications 2009;9:41-8.

[22] Pang P, Andreana S, Aoki A, et al. Laser energy in oral soft tissue application: a position paper. J Laser Dent 2010;18(3):123-31.

[23] Mani A, Mani S, Shah S, et al. Management of gingival hyperpigmentation using surgical blade, diamond bur and diode laser therapy: a case report. J Oral Laser Applications 2009;9(4):227-32.

[24] Goviia V, Gulati M, Govila S. Diode laser application in periodontics. Indian Journal of Dental Sciences 2011;3(5):64-7.
[25] Ozbayrak S, Dumlu A, Ercalik-Yalcinkaya S. Treatment of melanin-pigmented gingiva and oral mucosa by $\mathrm{CO}^{2}$ laser. Oral Surg Oral Med Oral Pathol Oral Radiol Endod 2000;90(1):14-5.

[26] Aggarwal A, Bala D, Arora S, et al. Treatment of gingival hyperpigmentation with diode laser-an aesthetic approach. Ind J Dent Sci 2012;4:61-2.

[27] Bhardwaj A, Uppoor AS, Naik DG. A comparative evaluation of management of melanin pigmented gingiva using a scalpel and laser. Journal of Interdisciplinary Dentistry 2014;4(3):135-9.

[28] Low SB. Lasers in surgical periodontics. In: Convissar RA, edr. Principles and Practice of Laser Dentistry. $2^{\text {nd }}$ edn. New York: Mosby 2016: p. 51-66.

[29] Azzeh MM. Treatment of gingival hyperpigmentation by erbium-doped: yttrium, aluminum and garnet laser for aesthetic purposes. J Periodontol 2007;78(1):177-84.

[30] Wise RJ, Chen CY, Kim DM. Treatment of physiologic gingival pigmentation with surgical blade: a 25-year follow-up. Int J Periodontics Restorative Dent 2018;(Suppl 38):s45-8. 